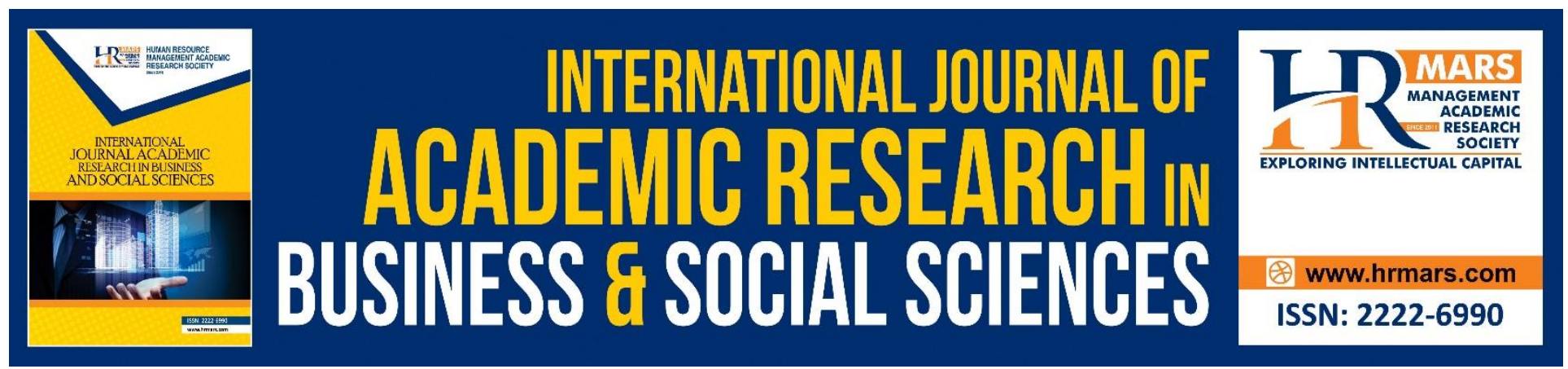

\title{
Vehicle Kilometer Travelled by Online Survey
}

Nurulhuda, J., Sharifah Allyana, M. R., Azzuhana, R., NurZarifah, H., and Khairil Anwar, A. K.

To Link this Article: http://dx.doi.org/10.6007/IJARBSS/v10-i10/8274 DOI:10.6007/IJARBSS/v10-i10/8274

Received: 04 September 2020, Revised: 19 September 2020, Accepted: 03 October 2020

Published Online: 28 October 2020

In-Text Citation: (Nurulhuda, et al., 2020)

To Cite this Article: Nurulhuda, J., Allyana, S. M. R., Azzuhana, R., NurZarifah, H., \& Anwar, K. A. K. (2020). Vehicle Kilometer Travelled by Online Survey. International Journal of Academic Research in Business and Social Sciences, 10(10), 1131-1136.

\section{Copyright: (c) 2020 The Author(s)}

Published by Human Resource Management Academic Research Society (www.hrmars.com)

This article is published under the Creative Commons Attribution (CC BY 4.0) license. Anyone may reproduce, distribute, translate and create derivative works of this article (for both commercial and non-commercial purposes), subject to full attribution to the original publication and authors. The full terms of this license may be seen at: http://creativecommons.org/licences/by/4.0/legalcode

Vol. 10, No. 10, 2020, Pg. 1131 - 1136

Full Terms \& Conditions of access and use can be found at http://hrmars.com/index.php/pages/detail/publication-ethics 


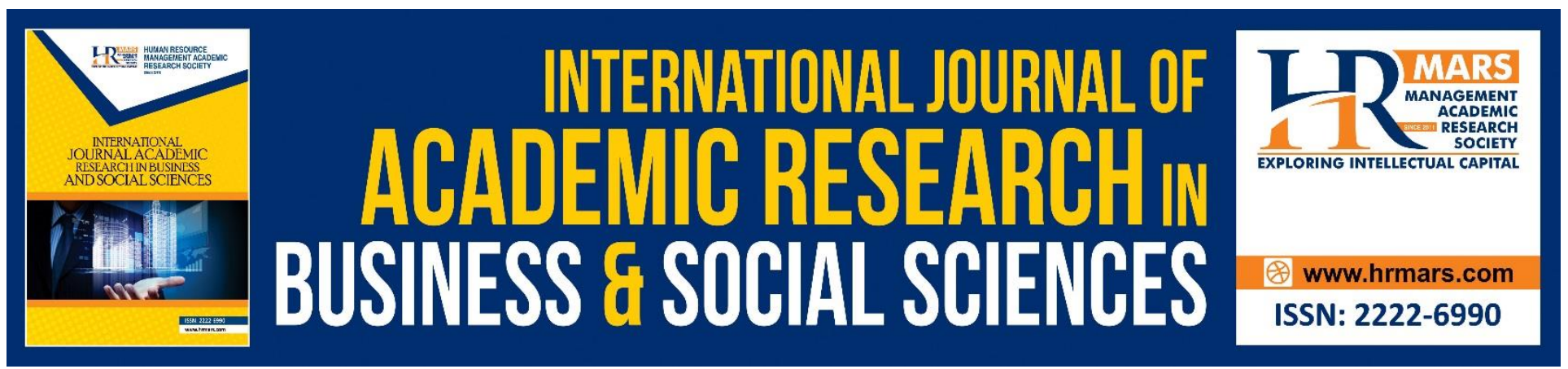

\title{
Vehicle Kilometer Travelled by Online Survey
}

\author{
Nurulhuda, J., Sharifah Allyana, M. R., Azzuhana, R., NurZarifah, H., \\ and Khairil Anwar, A. K. \\ Road Safety Engineering and Environment Research Center, Malaysian Institute of Road Safety \\ Research (MIROS) Kajang, 43000, Selangor,Malaysia
}

\begin{abstract}
Vehicle kilometer traveled often used to indicate levels of road safety. However, the previous survey on VKT data collection remains doubts as to the extent of the inadequacies due to low response and high cost. The main objective of this study is to compare online survey methods to develop an optimal survey strategy in data collection of the VKT data. This study has used the combination of a questionnaire by the online survey (Google Form) and social communication (WhatApps) survey. This study found that VKT online survey has a significantly higher proportion from the urban areas and a significantly lower percentage of the female respondent. Participants in the middle age responded better to the online survey. This study was suggesting that for the data collection on VKT by the mixed method (interview, telephone, mail, and online survey) strategy could use to increase a sample.
\end{abstract}

Keywords: Online Survey, Vehicle Kilometer Travelled, Odometer Reading, Road Safety, Index

\section{Introduction}

Road safety target has been established because of the positive impact in the safety intervention due to benchmarking against the world's best achievement, especially after the safety intervention. Radin (2005) was introduce new road safety targets based on deaths per billion kilometers traveled which describe the actual involvement in risky situations. There are three (3) road safety targets; deaths per 10,000 vehicles; deaths per 100,000 population; and deaths per billion vehicle kilometers travelled. Vehicle Kilometer Travelled (VKT) is kilometer travelled by the motor vehicle on the road during a given period of time. Since 2007, Malaysian Institute Road Safety Research (MIROS) work on estimated VKT from the odometer reading of the vehicle. The sample survey was conducted yearly, but a larger sample was needed to give a suitable precision to estimate of VKT for each state by type of vehicle. Australia Bureau of Statistic (ABS), selects 16,000 vehicles as samples to estimate 19 million motor vehicles (Australian Bureau of Statistics, 2019).

Several methods for collecting VKT data have been reported in the literature. Interview survey is a general method to obtain annual VKT through odometer reading White (1976); Collia, Sharp, \& Giesbrecht (2003) and Akmalia, 2017). Although interview survey is popular method, disagreement remains about cost, time-consuming and workforces. The other method that is regularly used is mail survey (Foldvary (1975); Harrison \& Christie (2005); Nurulhuda \& Jamilah (2010) and the Australian 
Bureau of Statistics (2010). However, the previous study shown the mail survey gained a lower response rate than the interview method, but it is an economical method in collecting exposure data. Due to the need to get VKT every year and improve the response rate in line with cost-effectiveness, several methods were designed by MIROS to increase the response rate and reduce non-sampling error. To ensure the VKT value is accurate and well representing Malaysia, it is necessary to get extensive coverage in terms of the number of respondent and area. Nowadays, internet usage in Malaysia has increased. $93.1 \%$ of users access the internet using smartphone and $98.1 \%$ users use WhatsApp's as the primary communication application (MCMC, 2018). It means the most of the internet user in Malaysia willing to answer the questionnaire when they are free, anytime and anywhere. Therefore, by using an online survey to obtain the odometer reading may provide a more straightforward and more cost- effective option.

This study is set out to identify the characteristic of respondent and to examine the benefits and challenges of the VKT data collection in online survey method. Many new techniques are being develop today, which are expected to provide the large sample with the low error in availability of data use in research and transportation policymaking.

\section{Material and Method}

This study used a web-based opt-in survey of convenience sampling. Methods propose here, used a combination of a questionnaire by online survey and social communication. These techniques were combined for the better result. The online questionnaire was designed by using Google Form. It is widely used as a tool for developing an online questionnaire. It creates a questionnaire form easily and is accessed by Google. Besides that, the data and information are automatically suited to Microsoft Office Excel format.

Respondent were first was asked their telephone number and it is compulsory. Afterwards, they were asked to complete their sociodemographic question, type of vehicle and odometer reading of the vehicle. The telephone number is important because, after 3 months, the question of odometer reading was repeated via WhatsApp's for the same respondent. This study that required the first odometer reading and second odometer reading to calculate the difference and estimate the distance. The estimated kilometer travelled per day was divided by the number of days that elapsed between the two of odometer readings. Figure 1 shows the cover snapshot of the VKT Online Survey.

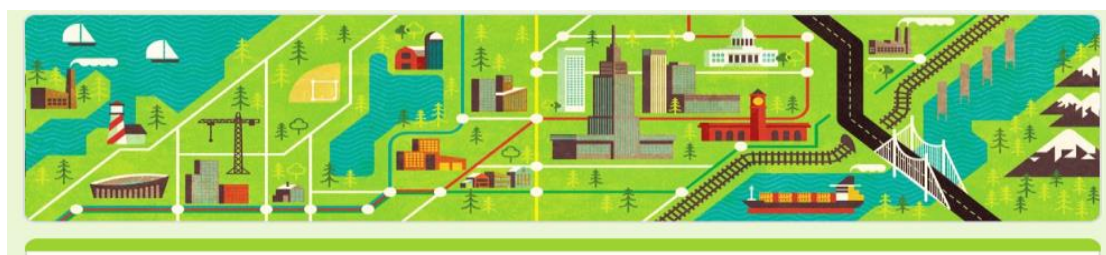

Soal Selidik Program Keselamatan Jalan Raya (MIROS)

Sukacita dimaklumkan soal selidik ini merupakan sebahagian daripada langkah kami ke arah mencapai matlamat Pelan Keselamatan Jalan Raya. Oleh itu kami amat berbesar hati sekiranya tuan/puan dapat memberi kerjasama dengan seikhlasnya menjawab soalansoalan berikut. Selepas 2 bulan dari tarikh anda mengisi borang ini, soalan selidik kedua akan kami hantar untuk mendapatkan bacaan odometer yang kedua. Perbezaan nilai odometer ini diperlukan untuk menganggarkan jarak perjalanan anda dengan menggunakan kenderaan tersebut. Nilai ini amat bermakna untuk mendapatkan penanda aras tahap keselamatan jalan raya di Malaysia. Segala maklumat yang diberikan oleh anda adalah sulit dan kami dahulukan dengan ucapan terima kasih.

Figure 1. The cover snapshot of the VKT Online Survey 
INTERNATIONAL JOURNAL OF ACADEMIC RESEARCH IN BUSINESS AND SOCIAL SCIENCES Vol. 10, No. 10, 2020, E-ISSN: 2222-6990 @ 2020 HRMARS

\section{Result}

A total of 226 participated in the Google Form survey. However, only 63 respondents completed the second odometer reading (return rate of about 28\%). It is possible that some respondents did not drive that vehicle any more, or that the telephone number is invalid.

Center, North, East Coast, South is representing Peninsular Malaysia. Centre represents the Kuala Lumpur, Selangor, Putrajaya. North represents Perak, Kedah, Penang and Perlis. East Coast represents Kelantan, Terengganu and Pahang. South represents Negeri Sembilan, Melaka, and Johor. The highest respondents are from the Centre area, which is $68.3 \%$, followed by the South area $14.3 \%$. East Coast area and Sabah and Sarawak area both 7.9\%. The lowest is North area, 1.6\%. Table 1 shows the area location by registered vehicle in 2018 provided from RTD Malaysia. This actual data presents the population of the respondent. However, the sample in an online survey is low, especially in the North area (1.6\% out of $22 \%$ ). This means that the sample does not represent the population.

Table 1: Percentage of Registered vehicle by location (Road Transport Department, 2018)

\begin{tabular}{|l|c|}
\hline Location & Percentage (\%) \\
\hline South & 19 \\
\hline Centre & 40 \\
\hline North & 22 \\
\hline East Coast & 9 \\
\hline Sabah and Sarawak & 10 \\
\hline
\end{tabular}

This study collected respondent gender from $87 \%$ of the male and $13 \%$ are female. It indicates that the VKT online survey has low response among females. These findings are in contrast with Rowen (2019) study in health profile online survey where the percentage of female respondents is higher than male. However, the RTD report in 2017 reported that the percentage male license holder is Malaysia is higher than female ( $58 \%$ and $42 \%$ respectively).

The highest percentage of respondents are 34 and 35 years old. The mean age is 34.8 years old. From this online survey, $97 \%$ of respondents have an income, and $3 \%$ are students. This result indicates that ages of more than 23 years old significantly own a vehicle for work purpose. Steyn et al (2019) in his study found young aged (less 30 years old) more likely to respond to telephone survey because they may have work commitments preferably these ages more than 30 years old. They are likely to respond to postal and online survey because they may have more time to complete surveys.

Table 2 shows the Average Vehicle Kilometer Travelled by type of vehicle with RSE\% value. The Average Kilometer Travelled for motorcars is $22,715 \mathrm{~km}$ and for motorcycle is $16,081 \mathrm{~km}$. The percentage of RSE for motorcycle is more than $10 \%$, and it is interpreting that sampling variability is high. The percentage of RSE for motorcycle is more than $10 \%$, and it is interpreting that sampling variability is high.

Table 2: Average Kilometer Travelled and percentage of Relative Standard Error (RSE)

\begin{tabular}{|l|c|c|}
\hline Type of Vehicle & Average Kilometer Travelled $(\mathrm{km})$ & RSE (\%) \\
\hline Motorcar & 22,715 & 8.7 \\
\hline Motorcycle & 16,081 & $11.83^{*}$ \\
\hline
\end{tabular}


INTERNATIONAL JOURNAL OF ACADEMIC RESEARCH IN BUSINESS AND SOCIAL SCIENCES Vol. 10, No. 10, 2020, E-ISSN: 2222-6990 @ 2020 HRMARS

\section{Conclusion}

This study is to identify the characteristic of respondent by using an online survey to estimate VKT. From this study, it is found that online survey missing data were not an issue, but the respondent may provide an inaccurate answer. The issue with online survey method is, the researchers are not able to control the background of the respondent, which include the demographic and location information. However, using interviewing surveys method, the researcher can control the sample area.

The online survey is fast data collection for a wide area and is low cost. But the response is low. With the addition, promotion about the survey it might increase the responses. Although the online survey has a broad geographic reach, from this study, it is found that the Central area has the best response numbers that are willing to answer the questionnaire. First, it might be the information about this survey reaches mostly to the Central people; and second, the online survey for VKT is rarely used by the people outside the Central area. The value of average kilometer travelled by using online survey has a high percentage of RSE, which shows that the error and sampling inconsistency is high. This study recommends that by using the online survey, researchers need to recruit multiple strategies to spread out the online survey such as advertisement through government website and prepare participation incentive. The initial cost might increase, but the response rate would be increased as well.

\section{Acknowledgement}

Authors acknowledge Malaysian Institute of Road Safety Research (MIROS) for support in carry out the research.

\section{Corresponding Author}

Nurulhuda Jamaluddin, Research Officer, Malaysia, nurulhuda@miros.gov.my, Lot125-135, Jalan TKS1, Taman Kajang Sentral, 43000 Kajang, Selangor, Malaysia.

\section{References}

Akmalia, S. (2017). Vehicle Kilometre Travelled Validation Study Vehicle Kilometre Travelled Validation Study.

Australian Bureau of Statistics. (2010). 9210 . 0 . 55 . 001 - Survey of Motor Vehicle Use : Data Cubes , Australia, 12 months ended 31 October 2010.

Australian Bureau of Statistics. (2019). 9208 . 0 - Survey of Motor Vehicle Use, Australia, 12 months ended 30 June 2018.

Collia, D. V., Sharp, J., \& Giesbrecht, L. (2003). The 2001 National Household Travel Survey: A look into the travel patterns of older Americans. Journal of Safety Research, 34(4), 461-470. https://doi.org/10.1016/j.jsr.2003.10.001

Foldvary, L. (1975). Road accident involvement per miles travelled (Part II). Accident Analysis \& Prevention, 11(2), 191-205. https://doi.org/10.1016/0001-4575(76)90003-8

Harrison, W. A., \& Christie, R. (2005). Exposure survey of motorcyclists in New South Wales. Accident Analysis and Prevention, 37(3), 441-451. https://doi.org/10.1016/j.aap.2004.12.005

MCMC. (2018). Internet Users Survey 2018 - Statistical Brief Number Twenty-Three. https://doi.org/ISSN 1823-2523

Nurulhuda, J., \& Jamilah, M. M. (2010). Development of Exposure Indices for Different Types of 
INTERNATIONAL JOURNAL OF ACADEMIC RESEARCH IN BUSINESS AND SOCIAL SCIENCES

Vol. 10, No. 10, 2020, E-ISSN: 2222-6990 @ 2020 HRMARS

Vehicle in Malaysia. MIROS Road Safety Conference, 108-116.

Road Transport Department. (2018). Total number of registered vehicles by State. Corporate and Research Unit, Road Transport Department.

Rowen, D., Carlton, J., \& Elliott, J. (2019). PROM Validation Using Paper-Based or Online Surveys: Data Collection Methods Affect the Sociodemographic and Health Profile of the Sample. Value in Health, 22(8), 845-850. https://doi.org/10.1016/j.jval.2019.03.015

Steyn, E., Groeneveld, J. C., Santos, J., Kruger, A., Mselegu, X. I., \& Schleyer, M. H. (2019). Trends in a recreational fishery for mussels in eastern South Africa, based on postal, telephone and online surveys. Ocean and Coastal Management, 179(February), 104863.

https://doi.org/10.1016/j.ocecoaman.2019.104863

Umar, R. S. R. (2005). Updates of Road Safety Status in Malaysia. IATSS Research, 29(1), 106-108. https://doi.org/10.1016/s0386-1112(14)60124-2

White, S. B. (1976). On the use of annual vehicle miles of travel estimates from vehicle owners. Accident Analysis and Prevention, 8(4), 257-261. https://doi.org/10.1016/0001-4575(76)900117 